\title{
Effect of rumen acid load on in vitro ruminal total bacteria and Fibrobacter succinogenes populations determined by real-time PCR
}

S Danesh Mesgaran, A Heravi Mousavi, J Arshami, A Vakili, S Ghovvati, H Jahani-Azizabadi

Ferdowsi University of Mashhad, Mashhad, Khorasan Razavi, Islamic Republic of Iran

Email: sadjaddm@yahoo.com

Introduction One consequence of feeding excessive amounts of rapidly fermentable carbohydrates in conjunction with inadequate fibre to ruminants is subacute ruminal acidosis, characterized by periods of low ruminal $\mathrm{pH}$. Fibrolytic bacteria are unable to maintain the $\mathrm{pH}$ inside their cells when ruminal $\mathrm{pH}$ is low (Russell and Wilson, 1996). Rustomo et al. (2006) evaluated the acidogenicity value (AV) of feeds using an in vitro laboratory technique. Danesh Mesgaran et al. (2009) demonstrated that various kinds of dairy diets with different NFC contents had different acidogenicity values. The aim of the present study was to evaluate the effect of rumen acid load on ruminal total anaerobic bacteria and Fibrobacter succinogenes populations determined by real-time PCR.

Material and methods Various commercial dairy diets (forage:concentrate as 1:1) containing different levels of non-fibre carbohydrates (NFC) were provided as low (LNFC), medium (MNFC) and high (LNFC) to obtain different AV (Danesh Mesgaran et al., 2009). The concentration of NFC in LNFC, MNFC and HNFC was 336, 366 and $371 \mathrm{~g} / \mathrm{kg}$ DM. The acidogenicity values of the diets were determined using the procedure as described by Wadhwa et al. (2001). One-gram (DM) of each diet was weighed and incubated, in triplicate, with $30 \mathrm{ml}$ of buffered rumen liquor comprising $60 \%$ buffer and $40 \%$ rumen liquor. The buffer was made up at $20 \%$ of the strength of the Tilley-Terry (1963) buffer. Cysteine hydrochloride monohydrate $(0.025 \% \mathrm{wt} / \mathrm{vol})$ was added just prior to incubations. The incubations were carried out in 100 $\mathrm{ml}$ bottles held in a water bath at $38.7^{\circ} \mathrm{C}$. After the incubation, samples were taken for DNA extraction $(0.2 \mathrm{ml})$. Then, 2 $\mathrm{ml}$ of the each bottle content were located into micro tubes containing $50 \mathrm{mg}$ (excess) of $\mathrm{CaCO}_{3}$ powder. The mixture was shaken manually for $5 \mathrm{~s}$, then centrifuged at $4000 \mathrm{rpm}$ for $10 \mathrm{~min}$ before analysis of $\mathrm{Ca}$ content of the supernatant using Atomic Absorption. The AV was calculated as the product of $\mathrm{Ca}$ concentration (from the analysis) and fluid volume (30 $\mathrm{ml}$ ) divided by the sample weight. DNA was extracted from the samples using the Bioneer Accuprep Genomic DNA Extraction Kit. The 16s rRNA gene-targeted primer sets used in the present study were forward: GTTCGGAATTACTGGGCGTAAA and reverse: CGCCTGCCCCTGAACTATC. Cycling conditions were $95{ }^{\circ} \mathrm{C}$ for 5 min, forty cycles of $95{ }^{\circ} \mathrm{C}$ for $15 \mathrm{~s}, 61{ }^{\circ} \mathrm{C}$ for $1 \mathrm{~min}$ and $72{ }^{\circ} \mathrm{C}$ for $30 \mathrm{~s}$; fluorescence readings were taken after each extension step, and a final melting analysis was obtained by heating at $0.1{ }^{\circ} \mathrm{C} / \mathrm{s}$ increment from 65 to $95{ }^{\circ} \mathrm{C}$, with fluorescence collection at $0.1{ }^{\circ} \mathrm{C}$ at intervals. Total bacteria concentration was determined relative to bacterial standard. Fibrobacter succinogenes population was expressed relative to quantification of the total bacterial population. Data were analyzed as a complete randomized design using GLM procedure of SAS (2003). Model was: Y $=$ Mean + Treatment + residual.

Results The AV of LNFC, MNFC and HNFC was 10.7, 11.2 and 11.9, respectively. Data on Table 2 showed that the Fibrobacter succinogenes population in LNFC were significantly higher than the other diets $(\mathrm{P}<0.05)$.

Table 1 In vitro DNA concentration of total bacteria and the population of the Fibrobacter succinogenes relative to total bacteria in commercial dairy diets containing different levels of NFC.

\begin{tabular}{llllll}
\hline \hline Bacteria & \multicolumn{3}{c}{ Treatments } & \multirow{2}{*}{ s.e.d } & \multirow{2}{*}{ P } \\
\cline { 2 - 5 } & LNFC & MNFC & HNFC & & \\
\hline Total bacteria $(\mathrm{ng} / \mu \mathrm{l})$ & 34.55 & 44.27 & 44.65 & 5.72 & $>0.05$ \\
Fibrobacter succinogenes & 0.1281 & 0.0310 & 0.0298 & 0.03 & $<0.05$ \\
\hline \hline
\end{tabular}

Conclusions The results of the present study demonstrated that increasing in NFC in commercial diets caused a decrease in ruminal AV and the population of Fibrobacter succinogenes. It was previously indicated that the rate at which rumen fluid $\mathrm{pH}$ changed followed a pattern similar to changes in the AV (Rustomo et al., 2006), and the differences in AV and pH changes likely were associated with the fermentability of the feeds. Therefore, higher NFC content in HNFC led to higher available nutrients for bacterial growth, and consequently lower $\mathrm{pH}$. This situation made a condition in which a rise in total bacteria might be assumed, with a decline in relative fibrolitic bacteria population, as demonstrated by the present results.

\section{References}

Russell, J.B., and Wilson D.B. 1996. Journal of Dairy Science. 79, 1503-1509

Rustomo, B., AlZahal, O., Cant, J. P., Fan M. Z., Duffield, T. F., Odongo, N. E., and McBride, B. W. 2006. Canadian Journal of Animal Science. 86, 119-126.

Wadhwa, D., Beck, N. F. G., Borgida, L. P., Dhanoa, M. S., and Dewhurst, R. J. 2001. Journal of Dairy Science 84, 11091117.

TILLEY, J., and TERRY, R. A. Journal of British Grassland Society. 1963. 18, p.104-111.

Danesh Mesgaran, S., Heravi Moussavi A., Jahani- Azizabadi H., Vakili A. R., Tabataiee F., and Danesh Mesgaran, M. 2009. Proceeding of the $\mathrm{XI}^{\text {th }}$ International Symposium on Ruminant Physiology. 146. 